\title{
Ecosystem Services Dynamics in Bogor Regency
}

\author{
Sri Lestari Munajatii ${ }^{1}$ Hariadi Kartodihardjo ${ }^{2}$, Muhammad Buce Saleh ${ }^{3}$ and Nurwadjedi ${ }^{4}$ \\ ${ }^{1}$ The Study Program of Natural Resources and Environmental Management, Graduate School of IPB University, Baranangsiang \\ IPB Campus, Bogor,West Java, Indonesia. \\ ${ }^{1}$ Geospatial Information Agency of the Republic of Indonesia, Jl. Raya Bogor KM 46 Cibinong Bogor, West Java Indonesia \\ ${ }^{2,3}$ Department of Forest Management, Faculty of Forestry, IPB University, Dramaga IPB Campus, Bogor, West Java Indonesia \\ ${ }^{4}$ Geospatial Information Agency of the Republic of Indonesia,Cibinong, Bogor, West Java Indonesia
}

Received: 2021-04-04 Accepted: 2021-07-26

\section{Keywords:}

ecosystem services;

land-use change;

land facets; conservation

Correspondent email: hariadi@apps.ipb.ac.id

\begin{abstract}
The decline in the quality of ecosystem services in Bogor Regency is indicated by the existence of various natural disasters in recent years. Prudent development must be carried out to minimize the impact of a decrease in the ecosystem services index. The purpose of this research is to map ecosystem services for food supply, water supply, water and flood management, and tourism aspects within 2000-2017. The data used were land cover and land facet maps at a scale of 1:25,000 obtained from BIG, accompanied by a reinterpretation process. The data sources were Indonesia's topographic maps (RBI), Citra SPOT 7, DEMNAS, and field surveys. The ecosystem services index (ESI) is calculated based on an analysis of changes in land use and land facets. The value of ESI was weighted using analytic hierarchy process approaches to each of the variables assessed by experts. The results showed that the largest changes in land use occurred in residential and forest areas. The residential area increased by $1.96 \%$, while the forest area decreased by $1.8 \%$ in 17 years. Bogor Regency is dominated by forest and rice fields which are spread over four main landforms, namely volcanic, structural, fluvial, and karst. The most significant increase of $5.65 \%$ was found in the clean water provisioning function, while the most significant decrease of $38.47 \%$ was found in the tourism and ecotourism sector. Accumulatively, the increase in ESI was 23\%, while the decrease was $20.64 \%$. Mitigation efforts that can be done are to maintain the availability of green open space by implementing strong regulations.
\end{abstract}

@2021 by the authors. Licensee Indonesian Journal of Geography, Indonesi

This article is an open access article distributed under the terms and conditions of the Creative Commons

Attribution(CC BY NC) licensehttps://creativecommons.org/licenses/by-nc/4.0/.

\section{Introduction}

A common issue encountered by developing countries including Indonesia is uncontrollable population growth. The Statistics Indonesia (BPS) in 2020 noted that in the last 10 years there was a population increase of 32.56 million people so that currently the total population of Indonesia has reached 270.20 million (BPS, 2020a). The increasing number of populations causes a quite high housing need. Agricultural land conversion into settlements is inevitable to meet the housing needs (Andriamasari et al., 2015; Fajarini et al., 2015; Pribadi et al., 2006). As a consequence, there are several environmental problems, such as river pollution, floods, and decreased green open spaces.

Bogor Regency has a good land capability for agriculture and green open spaces- Bogor Regency has a good land capability for agricultural cultivation and the provision of green open space, but land conversion is quite high. The reduction in green open space has an impact on decreasing the capacity of water catchment areas and disrupting the function of water flow (Fajarini, 2014; Kubangun et al., 2016; Setiawana et al., 2015; Lisnawati \& Wibowo, 2010). Reduced green open space reduces the capacity of catchment areas and disrupts the function of water flow. Unless planned and managed properly, the conversion of green open space may also lead to natural disasters and environmental degradation. Recent studies have revealed that the forests upstream of
Bogor Regency are in a critical condition (Sukwika et al., 2018; Kubangun et al., 2016).

Land conversion in the upstream also exacerbates the condition of the catchment area. A decrease in discharge and water quality has also occurred in Bogor Regency, caused by an increase in community activities (Elfidasari et al., 2015; Aristawidya et al., 2020). Bogor Regency also has 101 lakes, but only 52 of which function properly while the others are damaged (Suryanta, 2016). Further, Fauzielly et al., (2018) mentioned that in 2009-2017, 147 landslides occurred in Bogor Regency which killed a total of 83 people. One of the efforts to reduce the negative impacts of land conversion is through spatial planning based on ecosystem services.

Ecosystem services are defined as the benefits that humans can gain from nature (Watson et al., 2018; Kertesz et al., 2019). Ecosystem services are grouped into four: provisioning, regulating, cultural, and supporting services. There are several methods to identify the ecosystem services of a region, namely table calculations, expert proxy identification, regression modeling, and mapping through field surveys (Martinez-Harms \& Balvanera, 2012). Identifying ecosystem services through mapping can provide a comprehensive analysis of the spatial configuration of an area (Malinga et al., 2015). The data of ecosystem services mapping can also be used as a basis for spatial planning 
analysis and conservation (Burkhard et al., 2013; Egoh et al., 2008; Osvaldo et al., 2000).

This study aimed to assess the ecosystem services in terms of the functions for food and clean water provision, water and flood management, as well as tourism and ecotourism in 2000-2017. The four elements of ecosystem services were processed to provide a comprehensive picture of the condition of the ecosystem services in Bogor Regency. The semi-detailed ecosystem services map resulted in this study can provide new insights for policymakers and researchers especially related to ecosystem services management.

\section{Methods}

This study was conducted in Bogor Regency, West Java Province, which is located $20 \mathrm{~km}$ in the south of Jakarta, the capital city of Indonesia (Figure 1). Bogor Regency is one of Jakarta's satellite cities, so it has quite high interactions with the capital city. Bogor Regency consists of 44 subdistricts and 434 villages of which the capital is Cibinong. The population in Bogor Regency reaches 6,088,233 people with an almost equal proportion of men and women. The total workforce reaches 4.2 million and 1.3 of them also work as laborers/ employees. However, the number of casual workers in agriculture is only around $0.0276 \%$ of the total workforce (BPS, 2020b). This indicates that agricultural activities are no longer interesting for the people who live in Bogor Regency.

The ecosystem services index was evaluated using a spatial approach. This approach was used to determine the location, area, and distribution of each element of ecosystem services. The data used in mapping the ecosystem services was land use and ecoregion/landscape data (Burkhard et al., 2012; Young et al., 2012; Swetnam et al., 2010). The land use data at a scale of 1:25,000 were obtained from an interpretation of orthorectified Citra SPOT-7 taken in 2017 by the Geospatial

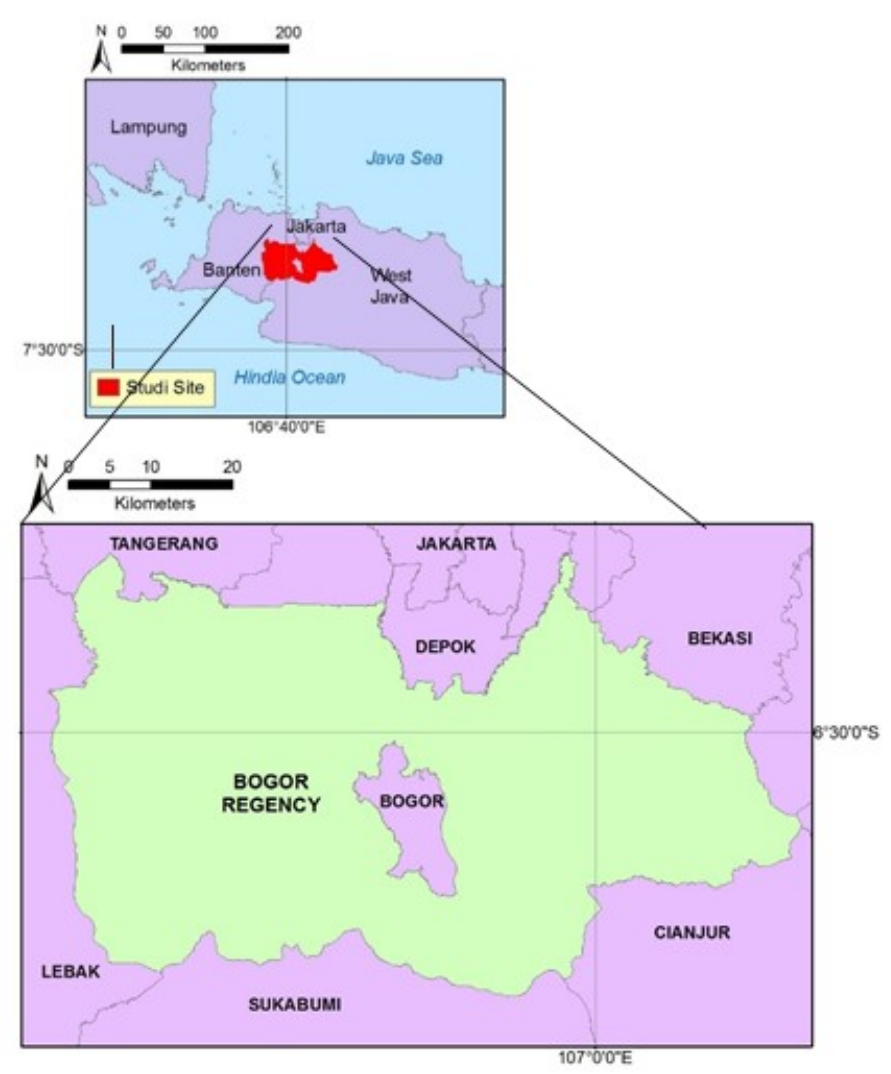

Information Agency (BIG). A field survey in 2020 was conducted to test the accuracy of the land use map resulted. The accuracy was tested based on the producer's accuracy, user's accuracy, overall accuracy, and the Kappa statistic (Congalton \& Green, 1999; Kosasih et al, 2019).

Ecoregion data at a scale of 1:25,000, also known as land facet data, were obtained from BIG. The land facet data were produced by BIG in 2019. Re-delineation, reinterpretation, and field surveys were carried out to correct errors in interpreting and naming the tentative maps of the land facet with databases DEMNAS (Indonesia's National Digital Elevation Model). The field survey was carried out in 2020 with point transects based on genetic diversity and land elevation. The distance between points is irregular and depends on the ease of land accessibility.

The ecosystem services index analyzed in this study consisted of these functions: a) provisioning clean water; b) provisioning food; c) regulating water and floods; and d) recreation and ecotourism. These four components of ecosystem services were selected by considering the fact that the main function of Bogor Regency is to support the environmental and tourism system of Jakarta. The operational elaboration of the four components of ecosystem services can be seen in Table 1 .

Table 1. Classification of ecosystem services (ES) and operational definition boundaries

\begin{tabular}{|c|c|}
\hline ES classification & Operational definition \\
\hline Food provision & $\begin{array}{l}\text { The provisioning function for plant- } \\
\text { based and animal-based food is from } \\
\text { agriculture, plantations, and animal } \\
\text { husbandry. }\end{array}$ \\
\hline $\begin{array}{l}\text { Clean water } \\
\text { provision }\end{array}$ & $\begin{array}{l}\text { The provisioning function for clean } \\
\text { water is from groundwater and surface } \\
\text { water, including its storage capacity. }\end{array}$ \\
\hline $\begin{array}{l}\text { Water and flood } \\
\text { management }\end{array}$ & $\begin{array}{l}\text { The regulating function for the hydro- } \\
\text { logical cycle as well as natural infra- } \\
\text { structure for water storage and mainte- } \\
\text { nance, as well as flood control efforts. }\end{array}$ \\
\hline $\begin{array}{l}\text { Recreation and } \\
\text { ecotourism }\end{array}$ & $\begin{array}{l}\text { The cultural function includes land- } \\
\text { scape features, natural uniqueness, and } \\
\text { certain values that become tourist at- } \\
\text { tractions }\end{array}$ \\
\hline
\end{tabular}

Source: MA, 2005 with modification

Weights of land use and facets for ecosystem services were based on the assessments of 35 experts. The results of the expert judgment were processed using the analytic hierarchy process (AHP) approach, which was then entered into the spatial data attribute. The overlay method in the form of intersect of land use data and land facets was conducted to obtain ecosystem service units. The ecosystem services index was calculated on the map attributes using a formula developed by Riqqi et al., (2018) with modifications. The modified formula for calculating the ecosystem services index is as follows.

$$
\mathrm{ESI}=\frac{\sqrt{E S I_{f a c} \times E S I_{l c}}}{\max \left(\sqrt{\left.E S I_{f a c} \times E S I_{l c}\right)}\right.}
$$

Figure 1. Study site 
where:

ESI : Ecosystem services index

ESI $_{\text {fac }}:$ :Ecosystem services index based on land facet

ESI $_{\text {ic }} \quad$ : Ecosystem services index based on land use

Max : Maximum value of the index synthesis result

\section{Result and Discussion}

Land Use Change Settings in Bogor Regency in 20002017

The results of the analysis showed that the most significant land-use changes were found in settlement areas and forests. Settlement areas will naturally grow rapidly, regarding the fact that Bogor Regency is a supporting area for Jakarta. This fact is in line with the findings of Widiatmaka et al., (2012) which stated that the economic expansion of Jakarta had an impact on the growth of settlements in Bogor Regency. In addition, a higher expansion in settlement areas was also found in the northern part because this area is relatively closer to Jakarta. Bogor Regency underwent a quite extensive settlement area expansion, with a percentage of $1.96 \%$ or 5,893.20 ha. Most of the settlement developments took place in Bojonggede, Cibinong, and Gunung Putri Subdistricts. One of the factors that drove people to reside in these subdistricts is accessibility, which is in the form of electric trains and toll roads. In addition, these areas are close to the capital of Bogor Regency, i.e. Cibinong, attracting developers to develop new settlement areas in these subdistricts.
Forests still dominated Bogor Regency in 2017 with a total area reaching 77,014.15 ha. Although the area decreased by $5,681.10 \mathrm{ha}$, the forests in the southern part are still well preserved. The forests are still maintained because Bogor Regency has two national parks, i.e. Mount Gede -Pangrango National Park and Mount Halimun - Salak National Park. Furthermore, there are some forests owned by the Indonesian State-Owned Forestry Company (Perhutani) whose land use is restricted, thus well maintaining sustainable forests. Spatially, forests are found in the southern and western parts of Bogor Regency (Figure 2). These areas are the favorite for local tourists and tourists from Jakarta because they have an attraction in the form of beautiful scenery and fresh air. In addition, forest conservation can also be a source of provisioning and regulating clean water for Bogor Regency and its downstream.

Paddy fields and moor fields also experienced extensive land-use changes from 2000-2017, where the total area of paddy fields increased, while moor fields decreased (see Table 2). The distribution of paddy fields in Bogor Regency does not have a special pattern, but it is almost even. In addition, the majority of the paddy fields are rainfed paddy fields with an area of approximately $60-70 \%$, while the remaining is irrigated. The irrigated paddy fields are mostly found in Tanjungsari, Cariu, and Pamijahan Subdistricts, each of which has an area of more than 2,000 ha. On the other hand, the rainfed paddy fields dominate Jonggol Subdistrict with an area of 2,434.90 ha. Accumulatively, the subdistrict with the

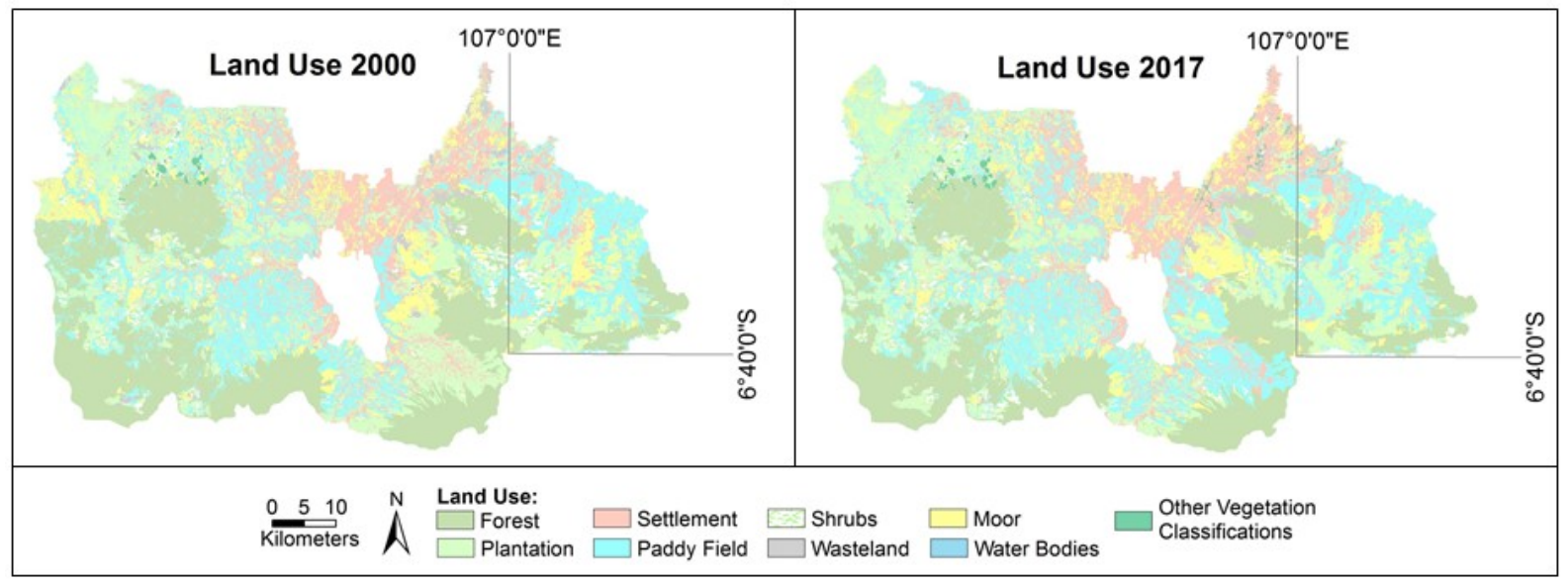

Figure 2. Land cover map in Bogor Regency in 2000 and 2017

Table 2. Land cover in Bogor Regency

\begin{tabular}{|c|c|c|c|c|c|}
\hline \multirow{2}{*}{ Landuse } & \multicolumn{2}{|c|}{ Area (ha) } & \multirow{2}{*}{ Gap } & \multirow{2}{*}{$(\%)$} & \multirow{2}{*}{ Information } \\
\hline & 2000 & 2017 & & & \\
\hline Forest & $82.695,25$ & $77.014,15$ & $5.681,10$ & 1,89 & Decreased \\
\hline Plantation/Garden & $60.539,88$ & $63.573,74$ & $3.033,86$ & 1,01 & Increased \\
\hline Settlements & $47.717,11$ & $53.610,30$ & $5.893,20$ & 1,96 & Increased \\
\hline Paddy Fields & $61.306,24$ & $65.138,10$ & $3.831,86$ & 1,28 & Increased \\
\hline Shrubs & $11.395,56$ & $9.003,10$ & $2.392,46$ & 0,80 & Decreased \\
\hline Wasteland & $4.722,17$ & $3.143,89$ & $1.578,28$ & 0,53 & Decreased \\
\hline Moor Fields & $28.489,70$ & $24.661,04$ & $3.828,67$ & 1,28 & Decreased \\
\hline Water Bodies & $2.431,89$ & $2.418,43$ & 13,46 & 0,004 & Decreased \\
\hline Other Vegetation Classification & 922,40 & $1.657,45$ & 735,05 & 0,24 & Increased \\
\hline Total & $300.220,19$ & $300.220,19$ & $26.987,92$ & 8,99 & - \\
\hline
\end{tabular}


largest paddy fields is the Jonggol Subdistrict with an area of 4,189.90 ha. Jonggol Subdistrict has extensive paddy fields because this subdistrict is far from the central business district (CBD), allowing its residents to depend on agriculture.

Moorfields also underwent land conversion because there were not many people who depended on their lives by planting on moor fields. The results of an interview with the village officials in 2020 showed that the Moorfields were not the primary source of livelihood for the community. The community members still relied more on paddy fields that produced rice, and only regarded the crops from the Moorfields as an additional income. This is evident by the presence of only narrow and partial moor fields without a clustering pattern. The survey conducted in 2020 also showed that most moor fields were not utilized, even neglected. This then resulted in paddy field conversion in 2000-2017 reaching $3,828.67$ ha or equivalent to $1.28 \%$. In 2017 , the remaining moor fields were $24,661.04$ ha or equal to $8.35 \%$ of the total area in Bogor Regency. East Bogor is the region with the most extensive moor fields.

Accumulatively, the plantation/garden area in this regency also increased by $1.01 \%$. The results of the satellite image analysis showed that plantations are spread in the western, southern, and eastern parts of Bogor Regency. The central and northern parts of Bogor Regency do not have many plantation areas because these areas are mostly used for industry and housing. The plantation area is dominantly for banana cultivation with an area of more than $50 \%$ of the areas for other commodities (BPS, 2020). Land conversion into plantation areas was mostly found in volcanic and structural landforms, located in the southern part of Bogor Regency (Munajati et al, 2019). The structural and volcanic landforms in Bogor Regency tend to have fertile soils yet require careful management because they mostly have undulating landscapes.

The accuracy of the land cover map in this study had a value of $94.81 \%$ with a kappa statistic of 0.93 . Most of the errors were dominated by misinterpretation of shrubs and fields or moorfields. Errors were also found because the land cover had changed in the last three years, while the databases used were images taken in 2017.

\section{Land Facet Setting in Bogor Regency}

The physical aspect analyzed in the assessment of ecosystem services is the landscape aspect. At a semi-detailed scale, the terminology for landscape is a land facet. In general, Bogor Regency is dominated by volcanic, structural, karst, and fluvial landforms (Munajati et al., 2019; Sumartoyo, 2010). The volcanic landform is located in the southern part, evident by the presence of three volcanic cones consisting of Mount Gede, Pangrango, and Salak. Structural landform can be identified by the presence of hills in the eastern and western parts. The next process is the development of karst and fluvial landforms due to endogenous processes.

The results of the land facet analysis showed that Bogor Regency consists of 28 landforms. Volcanic landforms dominate Bogor Regency. These landforms have long been known to have fertile soil conditions because soil rejuvenation takes place properly. The volcanic area in Bogor Regency however is not identical with agricultural land as in some other volcanic regions in Indonesia. This is because the volcanic areas in Bogor Regency function as forests. The existence of forests is protected by regulations, which prevent them from contributing optimally to food provision, yet allow them to have a major contribution to ecosystem services in terms of water management and recreation.

The structural area is dominated by low hills in sedimentary rocks with an area of $32,278.67$ ha. The structural landforms are widely used for plantation commodities. Interestingly, the structural areas in some locations are also used as rainfed paddy fields. The fact that rice plants are chosen instead of horticultural crops in an undulating landscape indicates that the community prefers growing staple food crops, i.e. rice. In this modern era of technology and transportation, it is quite easy to import food, especially rice, but people still try to reach food selfsufficiency even though it is quite challenging because they have to plant on the undulating landscape.

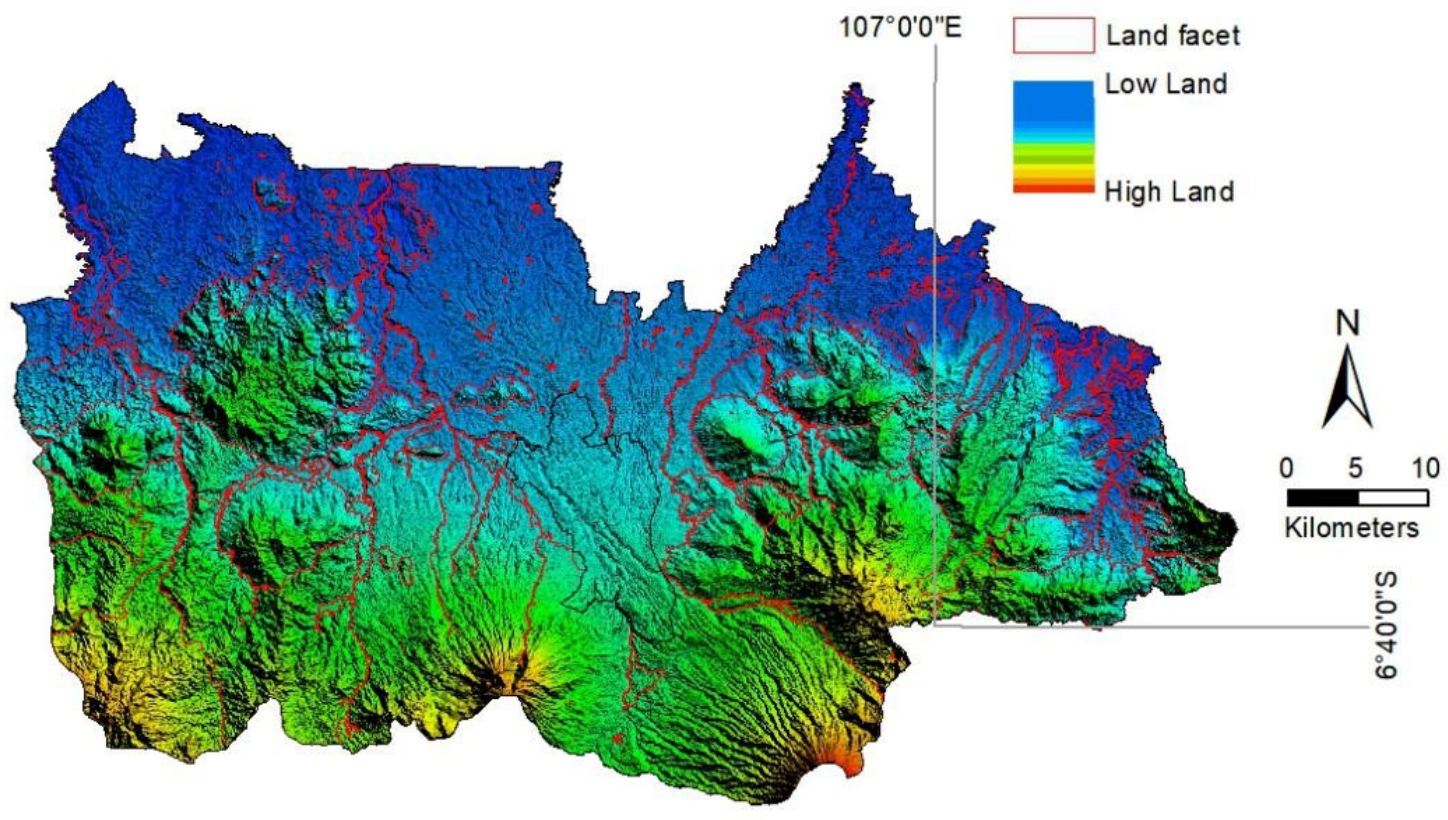

Figure 3. Land facet map of Bogor Regency 
Fluvial landforms dominate the northern part of Bogor Regency (Figure 3). These landforms are characterized by relatively flat areas with fertile surface soil material. The fertile material is due to the erosion process in the upstream, namely Mount Gede, Pangrango, and Salak which are carried by water flows. Fluvial landforms play an important role in ecosystem services, especially for provisioning food and regulating water. The presence of paddy fields in the northern part of Bogor Regency will increase the ecosystem services index for food provision in this region. Furthermore, the presence of several large lakes such as Lake Cikaret, Citatah, Gedong, and Bentenan can help water storage and maintenance in the research location.

The northern area, which is dominated by slightly incised alluvial fans, has high potential to be developed as an agricultural area, especially as paddy fields. Currently, there are still quite a few paddy fields in this area, but it is challenging to maintain the existence of the paddy fields. This is due to unstoppable population growth which causes housing needs to keep increasing over years.

The karst landforms are located in Klapanunggal, Ciampea, Gunung Putri, Ciseeng and Rumpin Subdistricts (Munajati et al., 2019; Putri et al., 2017). The karst landforms in Bogor Regency are used for mining materials instead of growing food crops. The economic value of limestone mining is higher than growing food crops.

\section{Ecosystem Services Analysis}

The results of the analysis showed that the highest water provision function is found in the land cover of forest and plantation with a value of 0.1406 . In good conditions, forests and plantations can absorb rainwater which then infiltrates into the ground, recharging groundwater aquifers or rivers. Furthermore, water bodies also play an important role in storing surface water so they have a quite high value, i.e. 0.125 . The lowest value of the water provision function is found on empty land, i.e. 0.0625 because surface water on empty land immediately runs off the land surface. The value of water provision and water and flood management has a fairly strong correlation. However, the role of water bodies is more significant than that of forests and plantations in terms of water and flood management. The value of water bodies reaches 0.1429 , while that of forests and plantations is 0.1286 .

Paddy fields have the highest weight in terms of food provision with a value of 0.1471 . Interestingly, the results of the expert judgment showed that moorfields have a lower weight than forests in terms of food provision although moorfields can yield food crops for consumption. The lowest weight in terms of food provision function is found in land cover in the form of settlements with a value of 0.073 . Plantations and forests also have a significant effect on recreational and ecotourism activities with a value of 0.1406 , including other non-cultivated plants with a value of 0.125 . This indicates that the main attraction for recreational and ecotourism activities in Bogor Regency is nature. This is understandable because most tourists come from Jakarta, who see skyscrapers almost every day. On the other hand, the land cover that is least contributing to recreational and ecotourism activities is empty land, with a value of 0.0469 .

Slightly incised alluvial fans and gently undulating volcanic plains are the land facets with the highest weight in terms of clean water and food provision. The results of sedimentation in the form of minerals and nutrients that fertilize the soil from the upstream of Bogor Regency stay on this land facet, allowing this area to be good as agricultural land. Shallow groundwater and abundant surface water also serve as added values for this area, making it have a high weight. However, the land facet, which is identical to natural border, has a minimal contribution to the function of water and food provision. This is caused by land with steep slopes that can neither be used for cultivating food crops nor absorb water.

The land facets that have a high contribution to water and flood management include: 1) gently to steeply undulating sedimentary plains; 2) slightly incised volcanic alluvial fans, and 3) gently undulating volcanic plains. The three land facets weigh 0.045 . These areas have a high weight in the function of water and flood management because these areas are the location of the reservoir and water management in Bogor Regency. There are at least more than 100 lakes throughout Bogor Regency (Suryanta, 2016). On the other hand, the land facet that has the highest weight in terms of supporting tourism and ecotourism activities is found in low hills in acid volcanic tuff and gently undulating volcanic plains. In addition, areas with a natural border setting still become the land facet with the lowest weight in terms of the four aspects of ecosystem services analyzed in this study.

The calculation of the result of integration between the weight of the land cover and land facets on water and food provision function in Bogor is still relatively low. The analysis results showed that $36.07 \%$ of the areas in Bogor Regency have a very low capacity in terms of food provision (Figure 4). This is quite unfortunate considering the fact that Bogor Regency has the physical potential to be developed as agricultural land (Azra et al., 2014; Trimarmanti, 2014). Worse, a new problem arises when food demand increases faster than food production (Dangulla et al, 2020; Saptana et al., 2013; Sulaiman et al., 2019).

In addition, the percentage of food and clean water provision was slightly declining. Accumulatively, the decline in clean water provisioning function reached $11 \%$ or equivalent to $34,614.55$ ha. This decrease was caused by the conversion of catchment areas into settlements in alluvial fans which could serve as groundwater reservoirs. Many of the paddy fields and moor fields in this area were also converted although the area also served food provisioning function.

Ecosystem services in terms of water and flood regulating functions in Bogor Regency also experienced a significant decrease, particularly in the northwestern to northern part (Figure 5). Although there has been no news about massive floods in Bogor Regency, it is necessary to carefully consider the decline in water and flood regulating function. Most of the decline was found in the northwestern to northern part with a decrease reaching 20.59\%. Bogor Regency received significant benefits by the existence of several large rivers and lakes which have brought tremendous impacts on water and flood regulation. In addition, it is also crucial to make river and lake normalization efforts to improve water and flood regulating function and reduce the negative impacts of future land-use changes.

There are some subdistricts with a very low index in terms of water and flood regulating function, such as Tanjungsari, Sukamakmur, and Cariu. Another interesting fact was found, i.e. there was a decline in the water and flood regulating function in the northwestern part, such as Jasinga and Tenjo 

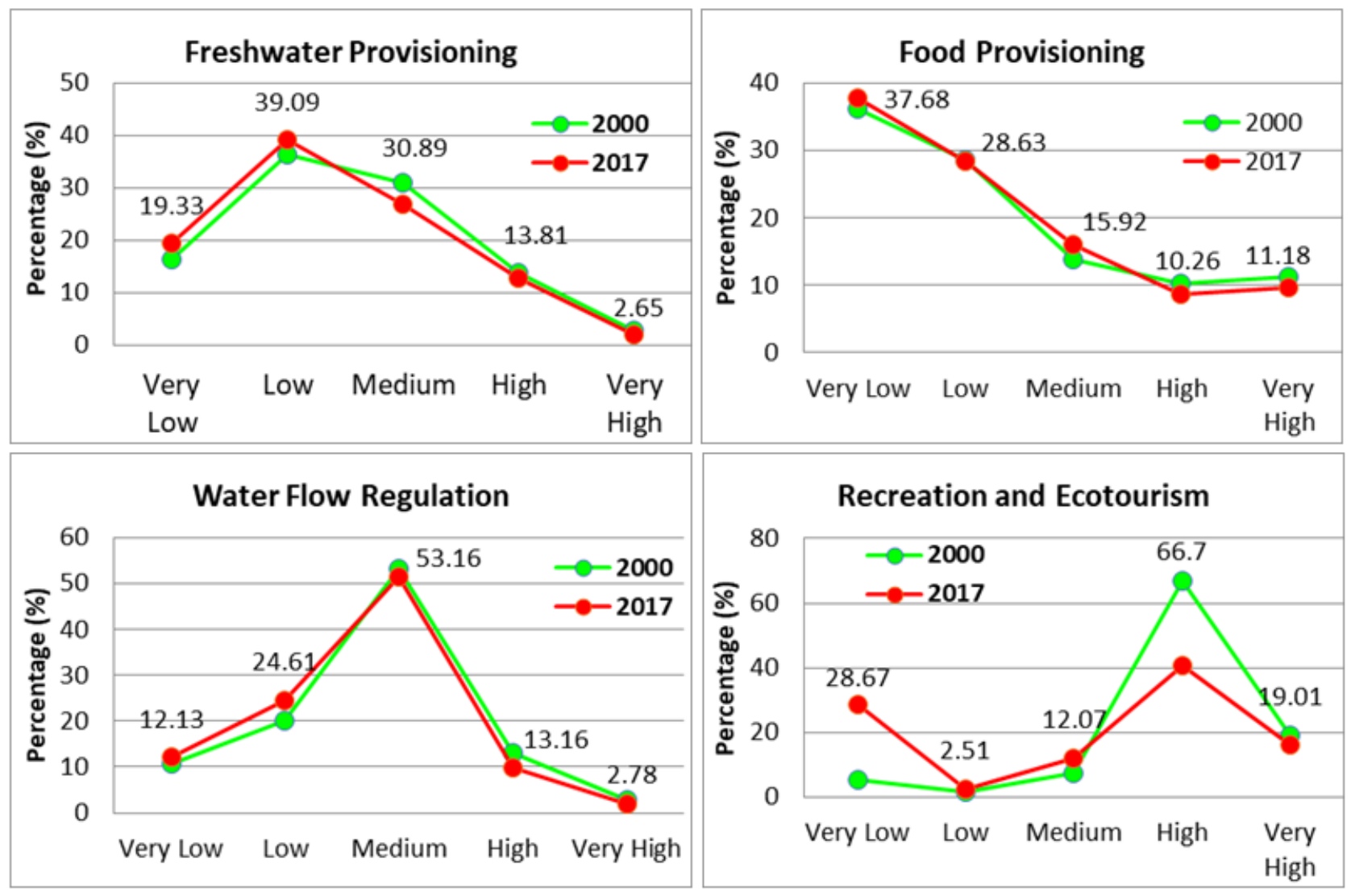

Figure 4. A comparison chart of ecosystem services index in 2000 and 2017

Subdistricts. These subdistricts still had an index of water regulating function at moderate to high levels. However, the decline in the period 2000-2017 was a serious warning for the government to pay attention to, so as to prevent floods from hitting in the future. The expansion of the satellite city has started to enter the northern border area. A real manifestation of the threat is when new housing clusters start to be built, which in the next few years will certainly create pocket neighborhoods and as a consequence will reduce agricultural land.

The greatest potential that Bogor Regency has is tourism and ecotourism. The accumulation index of tourism and ecotourism activities reaches 0.99 and the areas with a high index reach $66.70 \%$ in 2017 . On the other hand, the tourism and ecotourism sectors had different trends if compared to the other three aspects of ecosystem services. The northern part is not attractive for recreational activities because this area is a slope and filled with settlements and bald land. The southern part, however, presents natural tourism with a high index because this area has a unique and attractive landscape. Some areas in the southern part, for example, Puncak and National Park are still the main tourism choices with an index of almost one. The attractiveness of the tourism aspect can be seen from the relatively high settlement growth in the Puncak area. Lisnawati \& Wibowo (2010) also highlighted the phenomenon of increasing residential areas in Puncak due to the proliferation of new tourism areas.

The great tourism potential of this area should also be of serious concern for the government. This is because the highest decline in the quality of ecosystem services was found in this sector. Overall, the decline in tourism and ecotourism functions reached $115,483.94$ ha or $38.47 \%$ of the total area of
Bogor Regency. This means that there is a phenomenon concerning the land-use change system in Bogor Regency that requires a serious concern. It is also necessary to conduct a detailed study of the attractiveness and aesthetic value of landscapes to reduce the domino impact of land-use change for tourism and ecotourism sectors.

The accumulation of the four aspects of ecosystem services has a unique pattern. The areas with the highest index are located in Jasinga and Tenjo Subdistricts. The aspect of food and water provision has an important contribution to the high accumulation index of ecosystem services in this region. Spatially, the distribution extends to the northwestern part of Bogor Regency with an index of 0.98 . On the other hand, areas with a very low accumulation index are located in areas with natural borders and empty lands, such as Jonggol, Nanggung, and Cigudeg Subdistricts. A decline in the accumulative ecosystem services functions was found mostly in the central part, extending from the northern to the southern part (Figure 6).

The total area with the highest accumulative ecosystem services index fell in the very low category (Table 3). This requires a serious concern considering the fact that an increase of 10,951.68 ha occurred within 17 years. Areas with a very low index are mostly not productive and located far from the settlement areas, so these areas do not bring a very negative impact on human life. settlement areas. It is important to be dealt with and controlled so as not to harm and disrupt human activities in the surrounding. In addition, a decline in the quality of accumulative ecosystem service functions was in the high category, so it is necessary to design an appropriate and proper land management strategy to improve the ecological function of each land unit. 


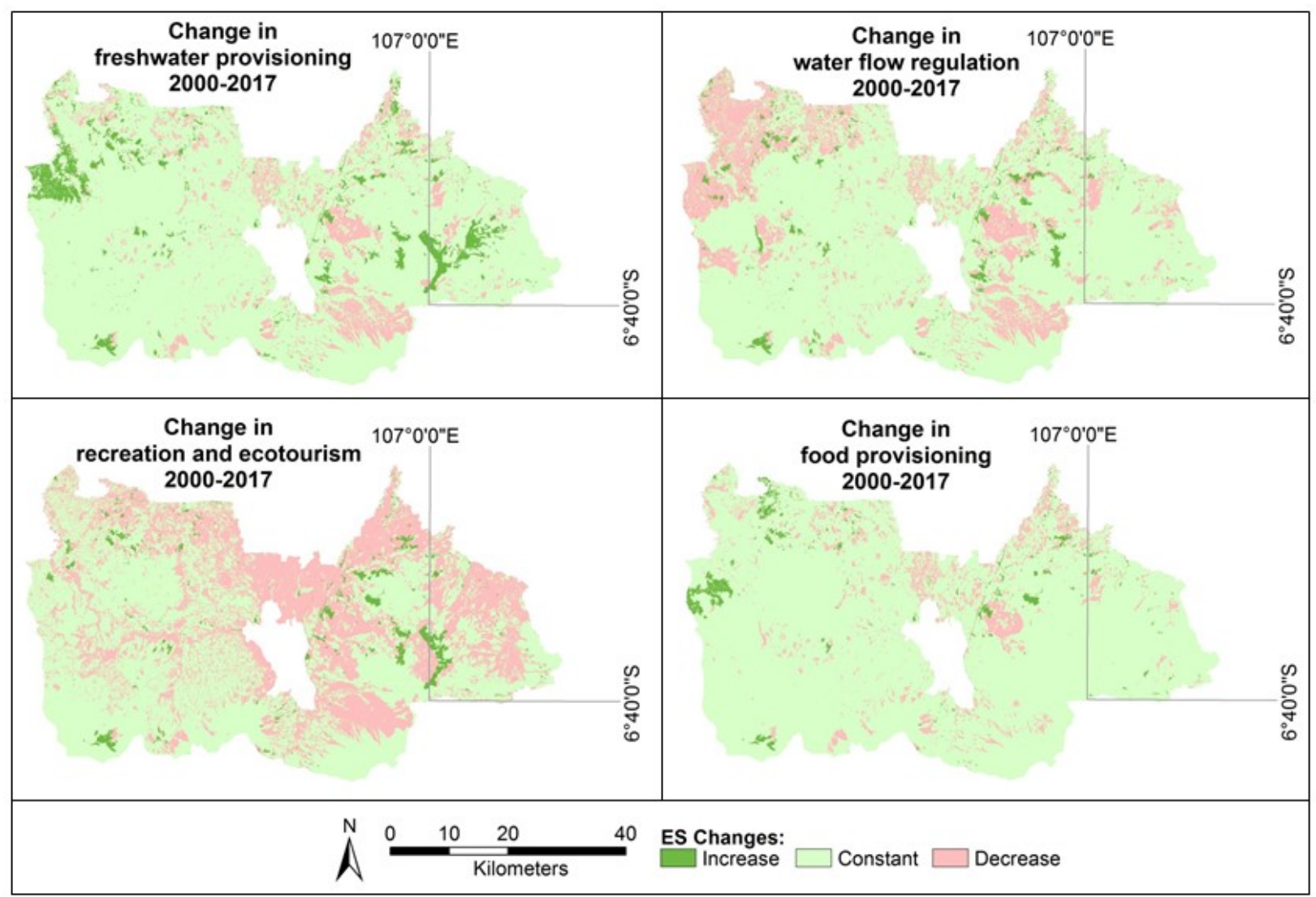

Figure 5. The changes of ecosystem services index from 2000 to 2017: a) clean water provision; b) food provision; c) water flow and flood regulation; and d) recreation and ecotourism

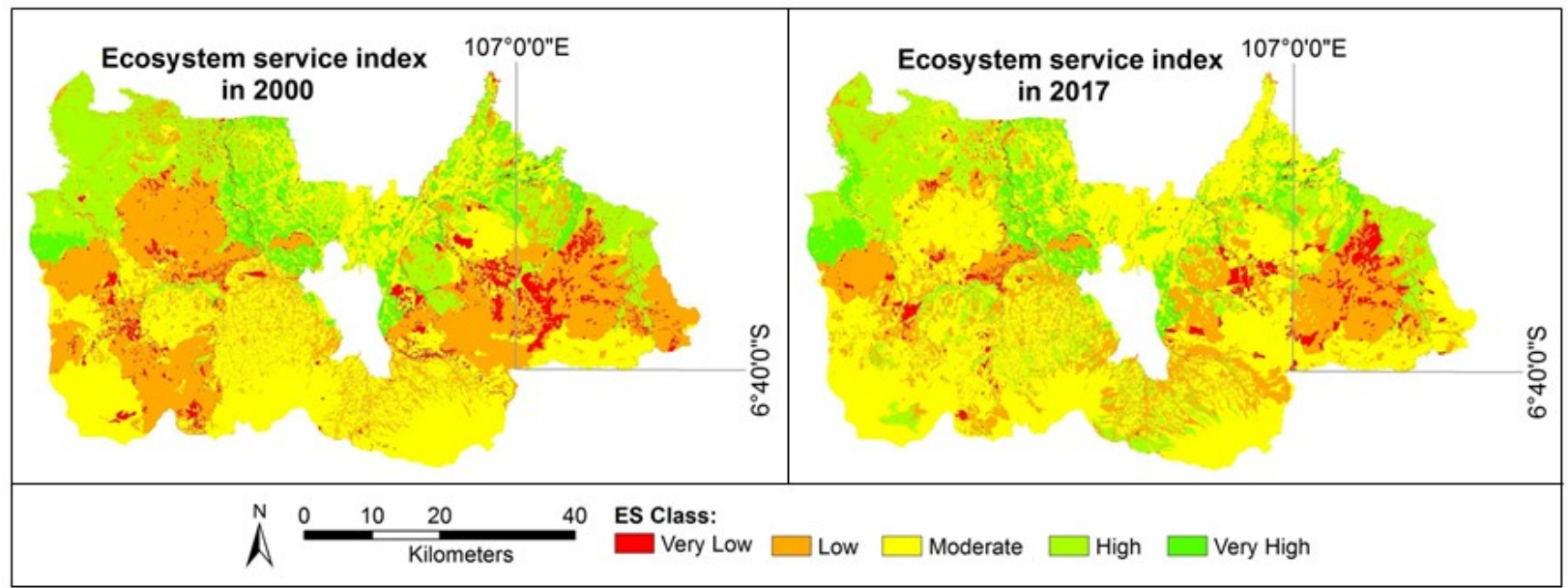

Figure 6. Distribution of accumulative ecosystem services index in Bogor Regency in 2000 and 2017

The decline in the ecosystem services index in Bogor Regency in $2000-2017$ was $22.97 \%$ or equivalent to $69,040.78$ ha. The spatial distribution of areas with a decline in the ecosystem services index was in clusters in the northern part of the center (Figure 7). One of the main factors causing the decline in this area is the land conversion into settlements. Four variables of the ecosystem services index were consistently affected by such land conversion, with tourism and ecotourism as the most significantly affected aspects. On the other hand, an increase in the quality of ecosystem services index was found in the western and eastern parts in clusters. The increase in the western part was extending from Cigudeg-Rumpin Subdistrict to the south to the Nanggung area. In the eastern part, there was a massive increase in
Babakanmadang, Sukamakmur, and Megamendung Subdistricts. The most dominant aspect which affected the increase in the quality of the ecosystem services index in this region is clean water and food provisioning functions. The increase in the quality of the ecosystem services index in 2000 -2017 was $20.64 \%$.

Areas that need careful supervision and management are scattered in parts of the sub-districts of Tajur Halang, Cibinong, Citereup to Gunung Putri. This is due to the fact that there are several locations with a low index and close to residential areas. The results of field checks carried out in 2020 show that the four sub-districts have a low capacity for clean water supply and water management. The domination of residential areas has made the area, not in favor of 
Table 3. Comparison of total area of ecosystem services index in Bogor Regency in 2000-2017

\begin{tabular}{|c|c|c|c|c|c|}
\hline \multirow[b]{2}{*}{ Category } & \multicolumn{2}{|c|}{ Area (ha) } & \multirow[b]{2}{*}{ Gap } & \multirow{2}{*}{$(\%)$} & \multirow[b]{2}{*}{ Status } \\
\hline & 2000 & 2017 & & & \\
\hline Very Low & $15,734.76$ & $26,686.44$ & $10,951.68$ & 3.65 & Increased \\
\hline Low & $95,545.82$ & $87,558.03$ & $7,987.78$ & 2.66 & Decreased \\
\hline Moderate & $115,844.82$ & $117,301.51$ & $1,456.68$ & 0.49 & Increased \\
\hline High & $50,749.05$ & $47,102.91$ & $3,646.13$ & 1.21 & Decreased \\
\hline Very High & $22,345.74$ & $21,571.30$ & 774.44 & 0.26 & Decreased \\
\hline Area & $300,220.19$ & $300,220.19$ & $24,816.71$ & 8.27 & - \\
\hline
\end{tabular}

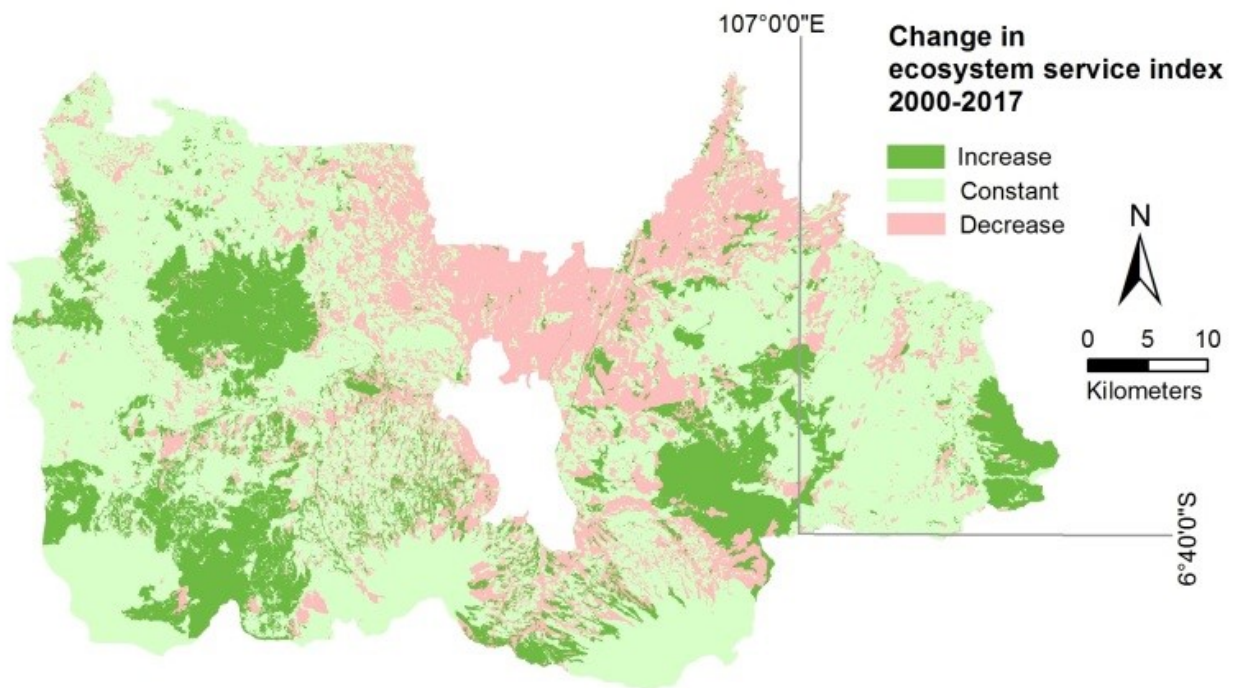

Figure 7. Map of accumulative ecosystem services index change in Bogor Regency in 2000-2017

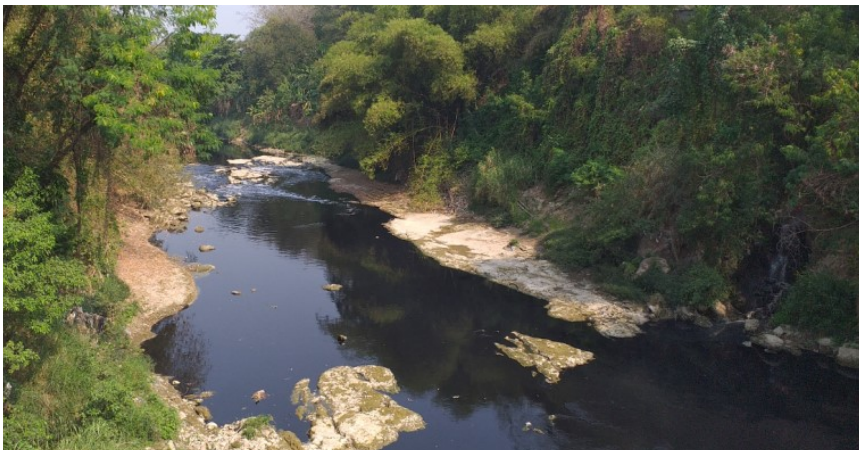

Figure 8. River water pollution due to factory waste in the Cikeas River

environmental sustainability aspects. The growth of developed land in this area also has implications for decreasing the quality of water infiltration (Oktariadi \& Riyadi, 2010). Maria et al., (2017) also found problems in the aspect of providing clean water, especially in karst areas. The construction of several large factories has also worsened the quality of the river that empties into Jakarta. Even liquid waste can be observed with the naked eye by changing the color of the river water to black in the Cikeas River (Figure $8)$.

Development that is not well planned and ecosystem management that is not well structured may increase the risk of natural disasters in Bogor Regency. Dani et al., (2017) revealed that only $38.06 \%$ of the area in Bogor Regency is in accordance with the spatial pattern. This indicates that there is a violation of the existing space utilization. Moreover, the issuance of new housing location permits, the establishment of industrial estates, and the construction of collector roads connecting to cities can trigger uncontrolled development (Maurinus et al., 2017.) Efforts to control ecosystems through monitoring and conservation and the application of strict rules can be carried out to minimize negative effects of the decrease in the value of the ecosystem services index in the area.

\section{Conclusions}

Accumulatively, the ecosystem services index in Bogor Regency tends to decrease. All sectors experienced a decline, and the largest decline occurred in the tourism sector, although this sector is still the most favored in Bogor Regency. The water and food provisioning function tend to be in the high category in the northern part, but it falls in the low category in the southern part, despite the fact that the ecosystem services index in the area also declines. The highest water and flood regulating function is found in the northwestern area. The highest tourism function is found in the southern area where the area is the tourism center of Bogor Regency.

The main factor for the decline in ESI from 2000-2017 was caused by changes in land use, while the land facet aspect did not matter because it was relatively stable. 
Mathematically, land cover in the form of vegetation such as forests, plantations, and agriculture can lead to higher ESI values. Conversion of vegetated land to non-vegetation in the north makes ESI in the area tend to below. Economic expansion from the direction of Jakarta and improvement in road accessibility led to the development of settlements and industrial estates in the northern part of Bogor Regency. The impact of economic growth from the direction of Jakarta was even felt up to Puncak, where new housing clusters and tourist spots began to proliferate. The development of these settlements has had a good impact on the economic growth of the community where many shopping centers have been established in recent years, however, the impact on the environment must be watched out for.

The future challenge of minimizing the impact of degradation of ecosystem services resulting from land-use change is one of land tenure. Many government regulations regarding green open space, preservation of paddy fields, and land conservation have been published. The problem is how to deal with non-government development and land use. Moreover, currently, the supervision related to building construction permits is not very orderly, thus causing uncontrolled construction. All these problems are the root of institutional problems. Research related to ecosystem services related to institutional aspects is interesting to be carried out in the future to address these issues.

\section{Acknowledgement}

We would like to thank the Indonesian Geospatial Information Agency (BIG) for providing data and other support for this research. We also thank all the experts who provided an assessment of ecosystem services in this research. We are grateful to Prof. Junun Sartohadi Gadjah Mada University for his very meaningful input to improve this research.

\section{References}

Andriamasari, H., Mugnisjah, W.Q., \& Munandar, A. (2015). Potencial and strategic development of peri-urban agriculture in Bogor District. Jurnal Ilmu Tanah dan Lingkungan, 17(2), 6974. DOI: https://doi.org/10.29244/jitl.17.2.69-74.

Aristawidya, M., Hasan, Z., Iskandar., Yustiawati., \& Herawati, H. (2020). Status pencemaran Situ Gunung Putri di Kabupaten Bogor berdasarkan metode STORET dan indeks pencemaran. Limnotek Perairan Darat Tropis di Indonesia 2020, 27(1), 2738. DOI: http://dx.doi.org/10.14203/limnotek.v27i1.311.

Azra, A.L.Z., Arifin, H.S., Astawan, M., \& Arifin, N.H.S. (2014). Characteristics analysis of pekarangan to support food consumption diversification of the household in Bogor Regency. Jurnal Lanskap Indonesia, 6(2), 1-11. DOI: https:// doi.org/10.29244/jli.2014.6.2.1-12.

Badan Pusat Statistik (BPS). (2020a). Hasil Sensus Penduduk (2020). Badan Pusat Statistik. Jakarta. Cited in https://www.bps.go.id/ pressrelease/2021/01/21/1854/hasil-sensus-penduduk2020.html. [5 May 2021].

Badan Pusat Statistik (BPS). (2020b). Kabupaten Bogor Dalam Angka. Badan Pusat Statistik Kabupaten Bogor. Bogor.

Burkhard, B., Kroll, F., Nedkov, S., \& Muller, F.(2012). Mapping ecosystem service supply, demand and budgets. Ecological Indicators, 21(2012), 17-29. DOI: https://doi.org/10.1016/ j.ecolind.2011.06.019.

Burkhard, B., Crossman, N., Nedcov, S., Petz, K., \& Alkemade, R., (2013). Mapping and modelling ecosystem services for science, policy and practice. Ecosystem Services, 4(2013), 1-3. DOI: https://doi.org/10.1016/j.ecoser.2013.04.005

Congalton, R.G., \& Green, K. (1999). Assessing the Accuracy of
Remotely Sensed Data: Principles and Practices. Boca Raton, Florida (US): CRC Press, Inc.

Dani, E.T., Sitorus, S.R.P., \& Munibah, K. (2017). Analisis penggunaan lahan dan arahan pengendalian pemanfaatan ruang di Kabupaten Bogor. Tata Loka, 19(1), 40-52.

Dangulla, M., Manaf, L.A., Mohammad, F.R., (2020). Spatiotemporal analysis of land use/land cover dynamics in Sokoto Metropolis using multi-temporal satellite data and Land Change Modeller, Indonesian Journal of Geography, 52(2), 306 -316. https://doi.org/10.22146/ijg.46615

Egoh, B., Reyers, B., Rouget, M., Richardson, D.M., Le Maitre, D.C., \& van Jaarsveld, A.S., (2008). Mapping ecosystem services for planning and management. Agriculture, Ecosystems and Environment, 127(2008), 135-140. DOI: 10.1016/ j.agee.2008.03.013.

Elfidasari, D., Noriko, N., Effendi, Y., \& Puspitasari, R.L. (2015). Kualitas air Situ Lebak Wangi Bogor berdasarkan analisa fisika, kimia dan biologi. Jurnal Al Azhar Indonesia Seri Sains dan Teknologi, 3(2), 104-112. DOI: http://dx.doi.org/10.36722/ sst.v3i2.193.

Fajarini, R. (2014). Dinamika perubahan lahan dan perencanaan tata ruang di Kabupaten Bogor. Thesis. IPB University. Bogor.

Fajarini, R. Barus, B., \& Panuju, D.R. (2015). The dinamics of landuse change and prediction 2025 also its associations with spatial planning 2005-2025 in Bogor Regency. Jurnal Ilmu Tanah dan Lingkungan, 17(1), 8-15. DOI: https:// doi.org/10.29244/jitl.17.1.8-15.

Fauzielly, L., Jurnallah, L., Jihadi, L.H., Aditio, M., Ramadhan, T.H., \& Mufti, I.J. (2018). Sosialisasi mitigasi bencana longsor di Daerah Hambalang, Kecamatan Citereup, Kabupaten Bogor. Dharmakarya: Jurnal Aplikasi Ipteks untuk Masyarakat, 7(1), 11-13. DOI : https://doi.org/10.24198/dharmakarya.v7i1.14770.

Kertesz, A., Nagy, L.A., \& Balazs, B. (2019). Effect of land use change on ecosystem services in Lake Balaton Catchment. Land Use Policy, 80(2019), 430-438. DOI : 10.1016/ j.landusepol.2018.04.005.

Kosasih, D., Saleh, M.B., \& Prasetyo, L.B. (2019). Interpretasi visual dan digital untuk klasifikasi tutupan lahan di Kabupaten Kuningan, Jawa Barat. Jurnal Ilmu Pertanian Indonesia, 24(2), 101-108. DOI: https://doi.org/10.18343/jipi.24.2.101.

Kubangun, S.H., Haridjaja, O., \& Gandasasmita, K. (2016). Model perubahan penutupan/penggunaan lahan untuk identifikasi lahan kritis di Kabupaten Bogor, Kabupaten Cianjur, dan Kabupaten Sukabumi. Globe, 18(1), 21-32. DOI: http:// dx.doi.org/10.24895/MIG.2016.18-1.391.

Lisnawati, Y., \& Wibowo, A. (2010). Analysis of water discharge fluctuation due to land use change in Puncak Area, Bogor District. Jurnal Penelitian Hutan Tanaman, 7(4), 221-226. DOI: 10.20886/jpht.2010.7.4.221-226.

MA (Millennium Ecosystem Assessment). (2005). Ecosystems and Human Well-being: synthesis. Island Press/World Resources Institute, Washington DC.

Malinga, R., Gordon, L.J., Jewitt, G., \& Lindborg, R. (2015). Mapping ecosystem services across scales and continents - A review. Ecosystem Services, 13(2015), 57-63. DOI: 10.1016/ j.ecoser.2015.01.006.

Maria, R., Fajar, R.L., Marganingrum, D., \& Purwoarmita, A. (2017). Penentuan jaringan air bersih dari mata air untuk mendukung ketahanan air daerah karst Lingarmukti, Klapanunggal, Kabupaten Bogor. Semimar Nasional Geomatika 2017, 89-97.

Martínez-Harms, M. J., \& Balvanera, P. (2012). Methods for mapping ecosystem service supply: a review. International Journal of Biodiversity Science, Ecosystem Services \& Management, 8(1-2), 17-25. DOI: https:// doi.org/10.1080/21513732.2012.663792

Maurinus, R.A.C., Rusdiana, O., \& Ichwandi, I.(2017). Dinamika perubahan dan kebijakan pemanfaatan ruang di Kabupaten Bogor, Provinsi Jawa Barat. Journal of Environmental Engineering and Waste Management, 2(2), 60-68. DOI: http:// dx.doi.org/10.33021/jenv.v2i2.220. 
Munajati, S.L., Kartodihardjo, H., Saleh, M.B., \& Nurwadjedi. (2019). Sensitivity analysis of ecosystem services especially food provisioning due to the dynamics of land use change in Bogor Regency, West Java, Indonesia. IOP Conf. Series: Earth and Environmental Science, 399(2019) 012024, 1-9. DOI:10.1088/1755-1315/399/1/012024.

Osvaldo, E.S., Chapin III, F.S., Armesto, J.J., Berlow, E., Bloomfield, J., Dirzo, R., Huber- Sanwald, E., Huenneke, L.F., Jackson, R.B., Kinzig, A., Leemans, R., Lodge, D.M., Mooney, H.A., Oesterheld, M., Poff, N.L., Sykes, M.T., Walker, B.H., Walker, M., \& Wall, D.H.,(2000). Global biodiversity scenarios for the year 2100. Science, 287(5459), 1770-1774. DOI: 10.1126/ science.287.5459.1770

Oktariadi, O. \& Riyadi, D. (2010). Geologi lingkungan untuk penentuan koefisien dasar bangunan wilayah Cibinong dan sekitarnya. Jurnal Lingkungan dan Bencana Geologi, 1(2), 91112. DOI: http://dx.doi.org/10.34126/jlbg.v1i2.9.

Pribadi, D.O., Shiddiq, D., \& Ermyanila, M. (2006). Model perubahan tutupan lahan dan faktor-faktor yang mempengaruhinya. Jurnal Teknologi Lingkungan, 7(1), 35-51. DOI: https://doi.org/10.29122/jtl.v7i1.364.

Putri, W.S., Qayim, I., \& Qadir, A. (2017). Soil seed bank of two karst ecosystems in Bogor, Indonesia: Similarity with the aboveground vegetation and its restoration potential. Journal of Tropical Life Science, 7(3), 224-236. DOI: http:// dx.doi.org/10.11594/jtls.07.03.07.

Riqqi, A., Hendaryanto, Safitri, S., Mashita, N., Sulistyawati, E., Norvyani, D.A., \& Afriyanie, D. (2018). Pemetaan jasa ekosistem. Seminar Nasional Geomatika 2018. DOI: http:// dx.doi.org/10.24895/SNG.2018.3-0.962.

Saptana, Sunarsih, \& Friyanto, S. (2013). Prospect of the model of sustainable food houses region (M-KRPL) and its KRPL replication. Forum Penelitian Agro Ekonomi, 31(1), 67-87. DOI: http://dx.doi.org/10.21082/fae.v31n1.2013.67-87.

Setiawana, G., Syaufina, L., \& Puspaningsih, N. (2015). Estimation of carbon stock loss from land use changes in Bogor Regency. Jurnal Silvikultur Tropika, 7(2), 79-85.

Sulaiman, A.H., Wahyuni, E.S., \& Adiwibowo, S. (2019). Strategy for strengthening the social capital of the women farmers in home garden utilization, Bogor District. Jurnal Penyuluhan, 15(2), 239 -253. DOI: https://doi.org/10.25015/penyuluhan.v15i2.27737.

Sukwika, T., Darusman, D., Kusmana, C., \& Nurrochmat, D.K. (2018). Skenario kebijakan pengelolaan hutan rakyat berkelanjutan di Kabupaten Bogor. Jurnal Pengelolaan Sumberdaya Alam dan Lingkungan, 8(2), 207-215. DOI: https://doi.org/10.29244/jpsl.8.2.207-215.

Sumartoyo. (2010). Estimasi potensi airtanah melalui pendekatan tipologi bentuklahan Wilayah Bogor Provinsi Jawa Barat. Globe, 12(1), 57-67.

Suryanta, J. (2016). Kualitas situ di Kabupaten Bogor berdasar interpretasi data satelit penginderaan jauh serta pengaruhnya dalam pengendalian banjir Sungai Ciliwung. Prosiding Seminar Nasional Geografi UMS Tahun 2016, 521-533.

Swetnam, R.D., Fisher, B., Mbilinyi, B.P., Munishi, P.K.T., Wilcock, S., Ricketts, T., Mwakila, S., Balmford, A., Burgess, N.D., Marshall, A.L., \& Lewis, S.L. (2010). Mapping socio-economic scenarios of land cover change: A GIS method to enable ecosystem service modelling. Journal of Environmental Management, 92(3), 563-574. DOI: 10.1016/ j.jenvman.2010.09.007.

Trimarmanti, T.K.E. (2014). Evaluasi perubahan penggunaan lahan kecamatan di Daerah Aliran Sungai Cisadane Kabupaten Bogor. Jurnal Wilayah dan Lingkungan, 2(1), 55-72. DOI: https:// doi.org/10.14710/jwl.2.1.55-72.

Watson, K.B., Galford, G.L., Sonter, L.J., Koh, I., \& Ricketts, T.H. (2018). Effects of human demand on conservation planning for biodiversity and ecosystem services. Conservation Biology, 33 (4), 942-952. DOI: https://doi.org/10.1111/cobi.13276.

Widiatmaka., Ardiansyah, M., \& Ambarwulan, W. (2012). Perubahan cadangan karbon organik tanah dalam konteks perubahan penggunaan lahan selama 2 dekade: studi kasus Kabupaten Bogor Provinsi Jawa Barat. Globe, 14(2), 170-177.

Young, R.H., Potschin, M., \& Kienast, F. (2012). Indicators of ecosystem service potential at European scales: Mapping marginal changes and trade-offs. Ecological Indicators, 21 (2012), 39-53. DOI: https://doi.org/10.1016/ j.ecolind.2011.09.004. 